DOI : 10.31357/fhssmph.2006.00699

\title{
An Analysis of Mass Movements in Kothmale Oya Catchment
}

\author{
By \\ H. M. Jayani Rupi Herath \\ Department of Geography \\ University of Sri Jayawardenepura
}




\title{
An Analysis of Mass Movements in
}

\section{Kothmale Oya Catchment}

\author{
By \\ Herath Mudiyanselage Jayani Rupi Herath \\ GS / SS / 1170 \\ Department of Geography \\ University of Sri Jayawardenepura
}

Thesis submitted to the University of Sri Jayawardenepura

for the award of the Degree of Master of Philosophy in Geography on $07^{\text {th }}$ February 2006 
I certify that the work described in this thesis was carried out by me under the supervision of

Prof. Lennart Stromquist - University of Uppsala - Sweden and

Dr. C.K.M. Deheragoda - University of Sri Jayewardenepura and a report on this has not been submitted in whole or in part to any university or any other institution for another Degree / Diploma

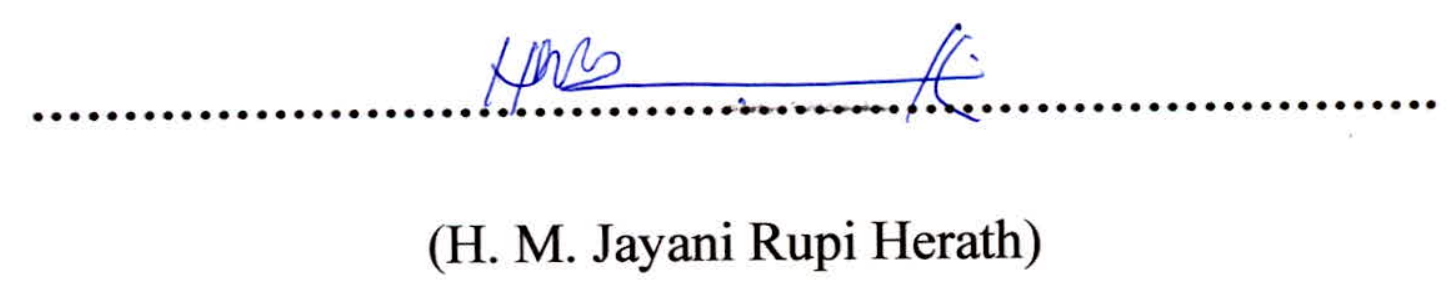


We certify that the above statement made by the candidate is true and that the work described in this thesis was carried out by this candidate under the supervision of us and this thesis is suitable for submission to the University

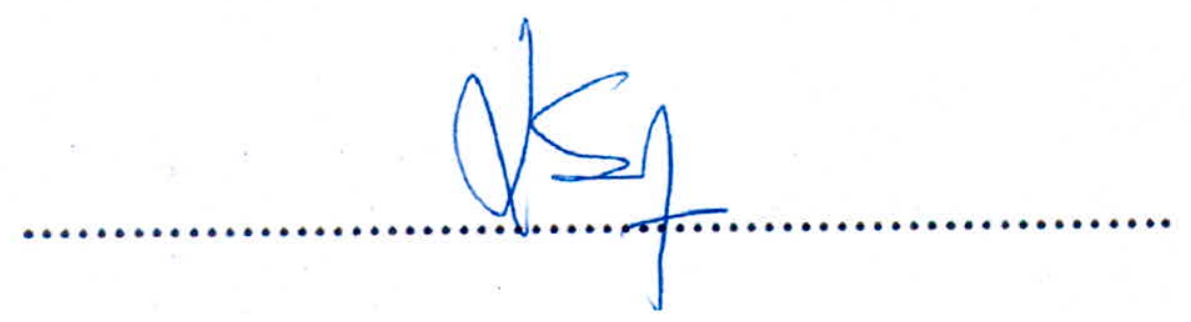

Prof. Lennart Stromquist

(University of Uppsala - Sweden)

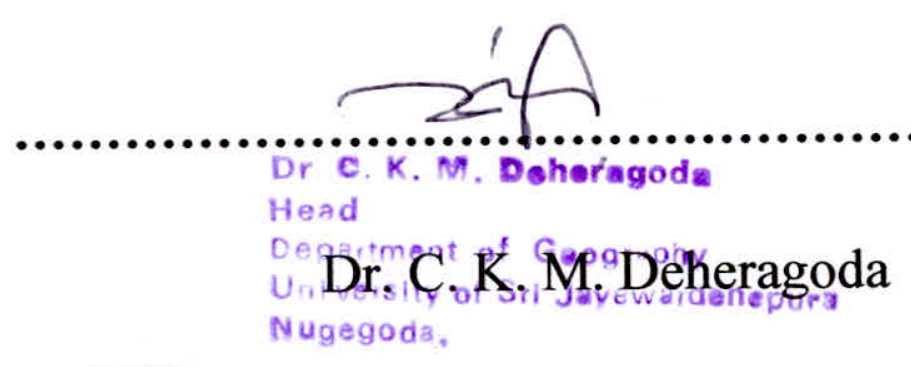

158 49 (athiversity of Sri Jayawardenepura)

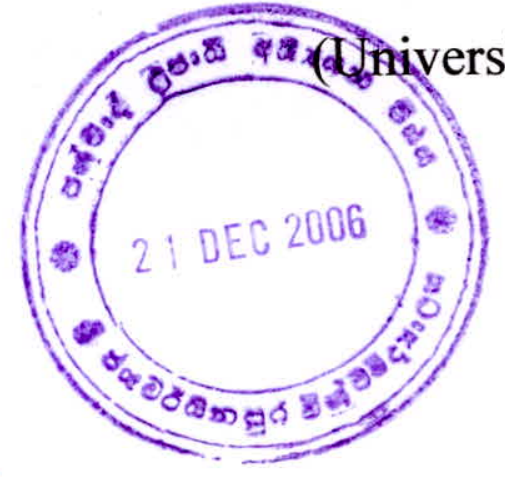




\section{TABLE OF CONTENTS}

I. TABLE OF CONTENTS I

II. LIST OF MAPS IV

III. LIST OF FIGURES VI

IV. LIST OF TABLES VII

V. ACKNOWLEDGEMENTS X $\mathrm{X}$

VI. ABSTRACT XI

CHAPTER ONE: CONCEPTUAL FRAMEWORK OF THE STUDY

$\begin{array}{ll}\text { 1.1. Concept of Landscape } & 01\end{array}$

1.1.1. Concept of Landscape Dynamics 03

1.1.2. Landscape Dynamics of Kothmale Oya Catchment 06

1.1.3. Interaction Between Landscape Dynamics and Mass Movements $\quad 10$

$\begin{array}{ll}\text { 1.2. Introduction to Mass Movements } & 10\end{array}$

$\begin{array}{ll}\text { 1.2.1. Types of Mass Movements } & 14\end{array}$

$\begin{array}{ll}\text { 1.3. Classification of Mass Movements } & 17\end{array}$

$\begin{array}{ll}\text { 1.3.1. Wyoming Landslide Classification Scheme } & 18\end{array}$

1.4 Triggering and Contributing Factors of Mass Movements 26

1.4.1 Forces and Triggering Factors of Mass Movements 27

1.4.2 Contributing Factors of Mass Movements 29

1.5 Man Made Impacts 31

1.6 Significance of Analyzing the Mass Movements 34

1.7 Methods of Analyzing Mass Movements 36

1.7.1 Constraints of Analyzing Mass Movements 38

1.7.2 Classification of Methods of Analyzing Mass Movements $\quad 40$ 


\section{CHAPTER TWO: INTRODUCTION}

2.1 Background to Mass Movements in Sri Lanka 50

2.2 Mass Movements in Central Highlands 53

2.3 Mass Movements of Kothmale Oya Catchment 55

2.4 Previous Studies of the Mass Movements in Kothmale Oya Catchment 62

2.5 Significance of the Study

$\begin{array}{lll}2.6 & \text { Aims } & 70\end{array}$

$\begin{array}{lll}2.7 & \text { Methodology } & 71\end{array}$

$\begin{array}{lll}\text { 2.7.1 Selection of the Study Area } & 71\end{array}$

$\begin{array}{lll}\text { 2.7.2 } & \text { Materials of the Study } & 73\end{array}$

$\begin{array}{lll}\text { 2.7.3 Methods of Data Analysis } & 75\end{array}$

2.8. Problems and Limitations of the Study 93

2.8.1. Limitations of the Study 93

2.8.2. Problems of the Study 95

$\begin{array}{lll}\text { 2.9. } & \text { Organization of the Thesis } & 97\end{array}$

CHAPTER THREE: KOTHMALE ENVIRONS AND THE STUDY AREA

$\begin{array}{lll}3.1 & \text { Introduction } & 99\end{array}$

$\begin{array}{lll}3.2 & \text { Topography } & 101\end{array}$

$\begin{array}{lll}3.3 & \text { Geology } & 103\end{array}$

$\begin{array}{lll}3.4 & \text { Soil } & 105\end{array}$

$\begin{array}{ll}\text { 3.5 Land Use and Vegetation } & 107\end{array}$

$\begin{array}{llr}3.6 & \text { Hydrology } & 110\end{array}$

$\begin{array}{llr}3.7 & \text { Climate } & 110\end{array}$

$\begin{array}{lll}3.8 & \text { Socio-Economic Background } & 112\end{array}$ 
4.1 Results \& Discussion from Field Observations \& Mass Movement Check List 114

$\begin{array}{ll}\text { 4.1.1 General Information on Sites of Mass Movements } & 115\end{array}$

$\begin{array}{ll}\text { 4.1.2 Analysis of Geomorphological Data } & 118\end{array}$

4.1.3 Causative Factors of Mass Movements in the Kothmale Oya Catchment 120

4.1.4 Mass Movement Types Observed in the Kothmale Oya Catchment 121

$\begin{array}{lll}\text { 4.1.5 Former Landslide or Not } & 124\end{array}$

4.1.6 Characteristics of the Slope and Mass Movements 126

4.1.7 Geological \& Soil Factors of Mass Movements 135

4.1.8 Hydrological Variables in Sites of Mass Movements 141

4.1.9. Relationship Between Mass Movements and Vegetation \& Land Use 145

4.1.10 Vulnerable Elements in Sites of Mass Movements $\quad 150$

4.2 Results Obtained from Aerial Photographs 152

4.2.1 Dynamics of Land Use of the Study Area 152

4.2.2 Interaction Between Dynamics of Land Use and

Mass Movements of the Study Area $\quad 166$

4.3 Analysis Using Satellite Remote Sensing $\quad 173$

4.3.1 Creation of Land Use Maps of 1992 and $2001 \quad 173$

4.3.2 Summary of Land Use Dynamics using

Satellite and Aerial Remote Sensing $\quad 176$

$\begin{array}{lll}\text { 4.3.3 Creation of Mass Movement Hazard Maps } & 177\end{array}$

CHAPTER FIVE: CONCLUSIONS

5.1 Conclusions

192

$\begin{array}{llr}5.2 & \text { Recommendations } & 199\end{array}$

$\begin{array}{lr}\text { REFERENCES } & 202\end{array}$

\section{ANNEXURE}




\section{LIST OF MAPS}

\section{CHAPTER 2}

2.1 Sites of Mass Movements in Sri Lanka $\quad 52$

2.2 Geology and Structure with Major Lineaments of Kothmale Project 57

2.3 Landslide Hazard Zonation Map of Nuwara Eliya District 67

$\begin{array}{lll}2.4 & \text { Selection of the Study Area } & 72\end{array}$

\section{CHAPTER 3}

$\begin{array}{llr}3.1 & \text { Kothmale Oya Catchment } & 99\end{array}$

$\begin{array}{ll}\text { 3.2 Map of the Study Area } & 100\end{array}$

$\begin{array}{lll}\text { 3.3 Topographical Regions of Kothmale Oya Catchment } & 101\end{array}$

$\begin{array}{lll}3.4 & \text { Geology Map of the Study Area } & 104\end{array}$

3.5 Generalized Soil Map of Sri Lanka and Soil Map of the Study Area 106

3.6 Land Use Map of Kothmale Oya Catchment 108

$\begin{array}{lll}\text { 3.7 Agro Ecological Regions of Sri Lanka } & 111\end{array}$

\section{CHAPTER 4}

4.1 Spatial Distribution of Sites of Mass Movements of the Study Area 117

4.2 Directions of Mass Movements in the Study Area $\quad 130$

4.3 Land Use of the Study Area $1972 \quad 154$

4.4 Land Use Map of the Study Area $1999 \quad 155$

4.5 Dynamics of Land Use types Between 1972 and 1999

4.6 Spatial Distribution of Sites of Mass Movements in the Study Area 168

4.7 Relationship Between Land Use and Mass Movements in the Study Area 169

4.8 Relationship of Dynamics of Land Use Between 1972 and 1999 to the Sites of Mass Movements $\quad 170$

$\begin{array}{lll}4.9 & \text { Land Use of the Study Area - } 1992 & 174\end{array}$

$\begin{array}{ll}4.10 & \text { Land Use of the Study Area - 2001 }\end{array}$ 
4.11 Digital Elevation Model of the Study Area - 2001

4.12 Digital Elevation Model of the Study Area - 1992

4.13 Mass Movement Hazard Map of the Study Area - 1992

- Combination of Slope Gradient and Land Use

4.14 Mass Movement Hazard Map of the Study Area - 2001

- Combination of Slope Gradient and Land Use

4.15 Geology Map of the Study Area

4.16 Surface Soil Cover Map of the Study Area Surrounding the Kothmale Reservoir 185

4.17 Distances from the Reservoir Zonation Map

4.18 Mass Movement Hazard Map

- Combination of Slope Gradient, Land Use, Soil Cover and Geology

4.19 Mass Movement Hazard Map

- Combination of Slope Gradient, Land Use, Distance to Reservoir and Geology

4.20 Mass Movement Hazard Map of the Area Surrounding the Kothmale Reservoir

- Combination of Land Use, Slope Gradient, Distance to Reservoir,

Geology and Surface Soil Cover 


\section{LIST OF FIGURES}

\section{CHAPTER 1}

1.1 Interactions of Basic Elements of Landscape 03

1.2 Wyoming Landslide Classification Scheme 20

1.3 Internal and External Forces of Mass Movement 27

1.4 Triggering and Contributing Factors of Mass Movement \& Effects and Impact by Man $\quad 33$

1.5 Classifications of Methods of Analysis of Mass Movements 46

\section{CHAPTER 2}

2.1 Relationships Between Direction of Cracks and Direction of Movement

\section{CHAPTER 3}

3.1 Sequential Distribution of the Ecological Units Surrounding the Reservoir

109

\section{CHAPTER 4}

4.1 Mechanism of Reservoir Induced Mass Movements

4.2 Mechanism of Rain Induced Mass Movements

4.3 Mechanisms of Translational Slides

4.4 Relationships Between Mass Movement and Slope Angle 128

4.5 $\mathrm{AA}^{\prime}$ Cross section - Kotagepitiya to Niyangamdora 131

4.6 $\quad \mathrm{BB}^{\prime}$ Cross section - Kotagepitiya to Koththunugoda 131

4.7 Probable Mechanism of Reservoir Induced Creeping Movements 133

4.8 Probable Mechanism of Reservoir Induced Translational Slides 134

4.9 Relationships Between Mass Movements \& Distance to the Reservoir 143

4.10 Comparisons of Land Use Types Between 1972 and 1999

4.11 Classifications of Mass Movement Hazard Zones

Surrounding the Kothmale Reservoir 


\section{LIST OF TABLES}

\section{CHAPTER 1}

$\begin{array}{lll}1.1 & \text { Abbreviated Classifications of Landslides } & 18\end{array}$

1.2 Comparison of Classificatory Factors Used by Nine Authors 19

1.3 Suggestions for J.P.E Data Collection Activities in Case of

Pyroclastic Debris Flows

\section{CHAPTER 2}

$\begin{array}{lll}2.1 & \text { Parameters of Analysis } & 75\end{array}$

2.2 Features of Causative Factors of Mass Movements in Kothmale Oya Catchment 77

2.3 Types of Land Use and Vegetation $\quad 80$

$2.4 \quad$ Definitions of Land Use Types $\quad 81$

2.5 Definitions of Vegetation Types $\quad 81$

2.6 Colour Key for Landsat \& Respective Land Use 86

2.7 Weights for the Mass Movement Hazard Map - Land Use \& Slope 89

2.8 Weight Range and Hazard Classes 90

2.9 Weights for the Mass Movement Hazard Maps for All Categories 92

2.10 Hazard Score for Creation of Hazard Maps for All Categories 93

2.11 Percentage of Reliability Accuracy in Classifying 2001 Satellite Image 94

\section{CHAPTER 3}

3.1 Slope Gradient Classes of the Study Area and their Relative Distribution $\quad 102$

3.2 Geological Classes of the Study Area and their Relative Distribution $\quad 104$ 
3.3 Geological \& Soil Classes of the Study Area and their Relative Distribution according to the Physiographic Regions of the Kothmale Catchment

\section{CHAPTER 4}

4.1 General Information on Sites of Mass Movements

4.2 Geomorphological Contribution to Mass Movements

4.3 Characteristics of Causative Factors of Mass Movements

4.4 Types of Mass Movements Observed in the Study Area

4.5 Relationship Between Previous Slides and Present Mass Movement

4.6 Contribution of Slope to Mass Movement

4.7 Geology and Soil Contribution to the Mass Movements

4.8 Relationship of Soil Moisture to Sites of Mass Movement

4.9 Distribution of Mass Movements in Sites with High Moisture Content

4.10 Distribution of Mass Movements in Sites with Low Moisture Content

4.11 Hydrological Contribution to the Mass Movements

4.12 Relationship Between Mass Movements \& Distance to the Reservoir

4.13 Contribution of Vegetation \& Land Use to the Mass Movements

4.14 Relationship Between Mass Movements \& Land Use Type

4.15 Relationship Between Mass Movements \& Vegetation Type

4.16 Vulnerable Elements

4.17 Land Use Analysis using 1999 Aerial Photographs

4.18 Land Use Analysis using 1972 Aerial Photographs

4.19 Gains of Land Use Types for 1999 
4.21 Loss and Gain Analysis of the Land Use Dynamics of the Study Area

4.22 Analysis of Net Gain or Loss of Land Use Types

4.23 Areas of No Change of Land Use

4.24 Comparison of Areas of No Change and Change of Land Use

4.25 Land Use Types Impounded by the Reservoir

4.26 Relationships of Observed (2004) \& Aerial Photo Interpreted (1999)

4.27 Dynamics of Land Use and its Relationship to Mass Movements

4.28 Dynamics of Land Use Using Satellite Images

4.29 Overall Land Use Dynamics Between 1972 and 2001 - 30 Years

4.30 Comparison of Hazard Between 1992 and 2001 - 10 Years

4.31 Comparison of Hazard With and Without the Effect of the Reservoir

4.32 Identified Hazard Zones of Mass Movements and Their Relative Situation 


\section{ACKNOWLEDGEMENTS}

I would like to express my sincere gratitude to my supervisor, Dr. C. K. M. Deheragoda for his generous assistance during the whole spectrum of process of my research. I thank especially for him for providing necessary facilities for the compilation of my thesis.

Subsequently I would like to extend my gratefulness to my foreign supervisor, Professor Lennart Strömquist (Department of Social and Economic Geography, University of Uppsala, Sweden) who has kindly guided me especially during the training at Sweden and for the provision of regular and valuable insights, thoughts, materials and equipment.

My special and sincere thanks go to Emeritus Professor, M. M. Karunanayake who has guided me from the initial stages and for facilitating me with financial support through the SIDA / SAREC Research Cooperation Project.

I would like to mention the name of Dr. Clas Lindberg of Department of Social and Economic Geography of Uppsala University, the collaborating Swedish University of SIDA / SAREC Research Cooperation Project for the facilities and financial assistance they have granted me.

I would also like to extend my thanks to all the members of the academic and non-academic staff of the Department of Geography.

Miss. Navaratne also is not forgotten in the process of extending gratitude, who helped me immensely during my field studies.

I would also like to offer sincere thanks to my husband Dr. Dilantha Dharmagunawardene, who gave me the all the encouragements and assistance to make this thesis a success.

I take this opportunity to dedicate the thesis to every resident of Kothmale valley who had sacrificed their native lands and properties for the development of the Kothmale project. They sacrificed their luminosity to illuminate us and they sacrificed their fertile, breadwinning lands to secure bread for the whole nation. 


\title{
An Analysis of Mass Movements in Kothmale Oya Catchment
}

\section{H. M. Jayani Rupi Herath}

\begin{abstract}
$\underline{\text { ABSTRACT }}$
Mass movements occur as gravitational forces exceed the strength of material in a slope and it is influenced by variety of factors interacting in complexity causing catastrophic disasters. There are various types of Mass Movements and they are classified using various classification schemes. One of the recognized systems of these is the "Wyoming Landslide Classification Scheme".

Sri Lanka is no exception in terms of natural disasters and the Central Highland areas were more prone to Mass Movements. The introduction of major transformations to the environment with the Accelerated Mahaweli Development has further contributed to this problem. Many studies have clearly shown that there is a significant increase of slope instabilities and Mass Movements following this significant alteration to the environment and this is especially true regarding the subtle and sensitive environment of the surrounding of the Kothmale Oya valley and its catchment area.
\end{abstract}

In order to identify the contributory and initiation factors of Mass Movements in Kothmale Oya Catchment, this study was carried out in identified 21 sites of Mass Movements in the surrounding of the Kothmale reservoir and various characteristics of each site were analyzed using field observations. Simultaneously, overall analysis of Land Use and Vegetation Dynamics was also carried out using Aerial and Satellite Remote Sensing where MFWORKS and Multispec software were used for in depth analysis.

The study reveals that the areas of Mass Movements within the Kothmale Oya Catchment can be classified in to two sets, depending on the major factors of contribution, namely Reservoir Induced Mass Movements and Rain Induced Mass Movements. These two different sets are 
having unique individual characteristic features that are clearly evident during the field observations of these sites.

The construction of Kothmale Reservoir directly and indirectly made pathways to above mentioned slope instabilities. Other than this major factor many other diverse factors interact and combine in complexity to influence for the occurrence of the Mass Movements. They include: topographical factors (presence of steep slopes), geological factors (presence of lineaments, anticlines and synclines), and climatological factors (the rain fall pattern of the region) as the natural contributors to this process. Also number of man made factors that contribute towards the dynamics of land use and vegetation to aggravate the burden of the causation and initiation of Mass Movements in the Kothmale Oya Catchment. The impact of the man made activities such as tea and vegetable cultivation on steep slopes with inefficient drainage systems, deforestation and unauthorized resettlements in the reserve areas of the Kothmale Reservoir are also immensely contributing to the causation of Mass Movements. 